\title{
Factors Related To Blood Pressure In Adults In The Intensive Care Unit Bhayangkara Hospital Raden
}

Said Sukanto Year 2019

\author{
Agung Wisnu Wibowo*, Erlin Ifadah, Jamiatun \\ Nursing Study Program, Faculty of Health Sciences \\ Respati University of Indonesia
}

\begin{abstract}
Blood pressure is a measure of the force that directs blood to flow through the body's circulation. Blood pressure is needed by the body to carry oxygen and other nutrients to the body's tissues. The purpose of this study was to determine the factors associated with blood pressure in patients in the Intensive Care Unit (ICU). This study uses a quantitative method with an analytic survey approach. The population in this study were all patients in the ICU ward at Bhayangkara Tk.I R. Said Sukanto Hospital, as many as 133 patients. The sample required in this study is 100 respondents. The statistical test used was chi square. There is a relationship between age $(p=0.032)$, gender $(p=0.016)$, medication $(p=0.009)$, and exercise $(p=0.000)$ with blood pressure in patients in the Intensive Care Unit (ICU) Bhayangkara Hospital Tk.I R. Said Sukanto. There was no relationship between races $(p=0.052)$. The results showed an association between age, gender, medication and exercise with blood pressure
\end{abstract}

Keywords: Age, Gender, Race, Medication, Exercise, Blood Pressure

\section{Background}

Patients in the Internsive Care Unit (ICU) are patients in a life-threatening condition due to single or multiple organ failure accompanied by hemodynamic disorders and there is still a possibility that they can be cured through intensive care, monitoring and treatment (Setiyawan, 2016). Hemodynamic monitoring is very important because it can be used to recognize shock as early as possible in critical patients (Ainnur, 2016).

The presence of hemodynamic disorders requires proper monitoring and treatment because hemodynamic conditions greatly affect the function of oxygen delivery in the body and involve the function of the heart organ, one of which is blood pressure which is the power needed to flow in the blood vessels and circulate to all parts of the body. man. Blood smoothly circulates to all parts of the body to function as a medium for transporting oxygen and other substances needed for the life of cells in the body (Moniaga, 2012). Changes in blood pressure both in a state of decreased consciousness and conscious state are strongly influenced by the presence of a stimulus. Stimulus can come from within as a manifestation of changes in the body's 
physiology as a result of the illness. In addition, the stimulus can come from outside the individual, both physical and social (Rihiantoro, 2010).

Blood pressure is a measure of the force that directs blood to flow through the body's circulation. Blood pressure is needed by the body to carry oxygen and other nutrients to body tissues. Without blood pressure, energy and essential nutrients for the heart, brain, kidneys, and other organs cannot be met (Townsend, 2010).

The World Health Organization (WHO) (2014) explained that increased blood pressure is one of the main risk factors for global mortality and is estimated to have caused 9.4 million deaths and 7\% of the disease burden as measured in the Disability Adjusted Life Year (DALY) in 2015. 2010. The global prevalence of elevated blood pressure (defined as systolic blood pressure and/or diastolic blood pressure $140 / 90 \mathrm{mmHg}$ ) in adults aged 18 years and over was approximately $22 \%$ in 2014 .

The prevalence of hypertension in Indonesia based on the Riskesdas survey in 2012 in the population aged 18 years was $25.8 \%$, the highest prevalence was in Bangka Belitung (30.9\%), followed by South Kalimantan (30.8\%), East Kalimantan (29.6\%) and West Java (29.4\%). Meanwhile, for Central Java Province (28\%), the prevalence of hypertension diagnosed by health workers was $9.4 \%$, those diagnosed by health workers or were taking medication was $9.5 \%$. The prevalence of patients who take their own medication is $0.1 \%$, those who have normal blood pressure but are taking hypertension medication are $0.7 \%$. So, the prevalence of hypertension in Indonesia is $26.5 \%$ (Balitbangkes, 2013)

The number of people with hypertension is estimated at 15 million in Indonesia but only $4 \%$ are able to control hypertension (controlled hypertension). What is meant by controlled hypertension are those who suffer from hypertension and realize that they are hypertensive and are on treatment so that they are controlled from possible attacks of excessive blood pressure increases (Bustan, 2015).

Factors that can cause an increase in blood pressure include age, race, gender, stress, medication, diural variations, exercise and hormones (Sudoyo, 2009). Along with increasing age, many changes will occur in humans, both changes in body and psychological functions due to the aging process. Blood pressure in the elderly (elderly) will tend to be high so that the elderly are at greater risk of developing hypertension (high blood pressure). Increasing age causes blood pressure to increase, because the arterial walls in the elderly (elderly) will experience thickening which results in the accumulation of collagen in the muscle layer, so that blood vessels will gradually narrow and become stiff (Anggraini et al, 2009).

Age which is a trigger factor for hypertension has been proven by Jolly (2015) who found age to be a factor in hypertension in a person, in his study $50 \%$ of participants aged 55-64 years and almost $70 \%$ of those aged 65 years had hypertension. The same opinion was also found from the results of Nabila's research (2014) on respondents aged 25 - > 75 years finding the highest incidence of hypertension in the 55-64 year age group, namely $28.6 \%$ in rural communities and $29.7 \%$ in urban districts. Bogor. The results of Cahyono's research (2008) regarding the high prevalence of hypertension caused by increasing age, where someone who is at risk of developing hypertension is someone who is over 55 years old. 
When we look at the comparison of the prevalence of hypertension between women and men, it turns out that the numbers vary. Irza (2009) in his research stated that hypertension was more experienced by women $(66.67 \%)$ while Sugihartono (2007) in his research in Jakarta (Petukangan) found that men had hypertension more than $14.6 \%$ of men.

Gender is also one of the factors that affect blood pressure (Rosta, 2011). Based on the results of research by Wahyuni and Eksanoto (2013), women tend to suffer from hypertension than men. In this study, $27.5 \%$ of women had hypertension, while for men it was only $5.8 \%$. Women will experience an increased risk of high blood pressure (hypertension) after menopause, namely age over 45 years. Women who have not menopause are protected by the hormone estrogen which plays a role in increasing levels of High Density Lipoprotein (HDL). Low HDL cholesterol levels and high LDL cholesterol (Low Density Lipoprotein) affect the process of atherosclerosis and result in high blood pressure (Anggraini et al, 2009).

The highest number of hypertension in Indonesia in 2000 was the Minang tribe. This is because the Minang tribe or people who live on the coast, usually consume more salt and like salty food (Cahyono, 2008). In general, men suffer from hypertension more than women, with a ratio of about $2.29 \%$ for an increase in systolic blood pressure. Men often experience signs of hypertension in their late thirties. Men are thought to have a lifestyle that tends to increase blood pressure compared to women (Herbert Benson, et al, 2012).

Another factor that affects the decrease in hypertension is the use of diuretic drugs as the first choice of antihypertensive drugs in the elderly because there is no significant difference in lowering blood pressure or in reducing mortality and in terms of the cost of using diuretics is cheaper. The exception is in patients with special indications for the use of other groups such as patients with post-myocardial infarction (beta blockers and ACEinhibitors), patients with diabetic nephropathy (ACE-inhibitors, ARBs). As a first therapy it is usually used as an adjunct. If a combination of 3 drugs is needed, diuretics, ACE-inhibitors or ARBs and CCBs can be given (Evi Sinaga, 2011).

Exercise can also reduce the risk of hypertension through mechanisms; decrease heart rate and blood pressure, decrease sympathetic tone, increase coronary artery diameter, and blood vessel collateralization system, increase HDL and lower blood LDL. Through sports activities, the heart can work more efficiently, the pulse frequency is reduced, but the pumping power of the heart is getting stronger, the heart's oxygen demand is decreased at a certain intensity, decreased body fat and weight and lowers blood pressure (Cahyono, 2008).

According to the results of a preliminary study conducted by researchers at the ICU of Bhayangkara Hospital Tk.I R. Said Sukanto, it was found that of the 5 patients interviewed, 3 of them were a man with an average age of 42 years. Of the 5 patients, 2 said they had a lot of thoughts so it was difficult to control their blood pressure. From the data above, the authors are interested in researching "Factors related to blood pressure in patients in the Intensive Care Unit (ICU) Bhayangkara Hospital Tk.I R. Said Sukanto". 


\section{RESEARCH METHOD}

This type of research is quantitative. The subject approach model used is an analytical survey approach. This research was carried out in the ICU room at Bhayangkara Hospital Tk $1 \mathrm{R}$. Said Sukanto. Research time The study was conducted in November 2019 February 2020. The population in this study were all patients in the ICU Inpatient Room of the Police Hospital from October to December 2019 as many as 133 patients. The sample in this study was the entire population in the form of patients in the ICU room at Bhayangkara Hospital Tk 1 R. Said Sukanto, 100 respondents using the Random Sampling technique.

\section{RESEARCH RESULT}

Univariate Analysis Results

Univariate analysis was carried out to determine the frequency distribution of each variable studied at the Kramat Jati Jakarta Police Hospital which is shown in the following frequency distribution table:

\begin{tabular}{|c|c|c|}
\hline Age & Total & $\begin{array}{c}\text { percent } \\
(\%)\end{array}$ \\
\hline $\begin{array}{l}\text { 26-35 years } \\
\text { (early adult) }\end{array}$ & 38 & 38 \\
\hline $\begin{array}{l}\text { 36-45 year } \\
\text { (later adult) }\end{array}$ & 62 & 63 \\
\hline Total & 100 & 100 \\
\hline
\end{tabular}

Based on table 1 shows the results that the proportion of respondents based on age, namely most of the respondents' ages are 36-45 years old or in the late adult category as much as $63 \%$
Table 2. Frequency Distribution of Respondents by Gender ( $n=100)$

\begin{tabular}{ccc}
\hline Sex & Total & $\begin{array}{c}\text { percent } \\
(\%)\end{array}$ \\
\hline Male & 41 & 41 \\
Female & 59 & 59 \\
\hline Total & 100 & 100 \\
\hline
\end{tabular}

Table 2 shows that the proportion of respondents who are mostly female is $59 \%$, while the proportion of respondents is male is $41 \%$.

Table 3. Frequency Distribution of Respondents by Race $(n=100)$

\begin{tabular}{ccc}
\hline Race & Total & $\begin{array}{c}\text { Percent } \\
(\%)\end{array}$ \\
\hline Java & 34 & 34 \\
Sunda & 26 & 26 \\
Betawi & 25 & 25 \\
Batak & 9 & 9 \\
Minang & 6 & 6 \\
\hline Total & 100 & 100 \\
\hline
\end{tabular}

Table 3 shows that the proportion of respondents mostly comes from the Javanese race with 34 respondents (34\%), the second largest Sundanese race respondents, namely 26 respondents (26\%), Betawi ranks third with 25 respondents (25\%), while Minang and Batak each numbered 9 and 6 respondents.

\section{Table 4 Distribution of Respondents Frequency Based on Medication $(\mathbf{n}=\mathbf{1 0 0})$}

\begin{tabular}{ccc}
\hline Medication & Total & $\begin{array}{c}\text { Percent } \\
(\%)\end{array}$ \\
\hline $\begin{array}{c}\text { Non Drug } \\
\text { Consumer } \\
\text { Drug } \\
\text { Consumer }\end{array}$ & 32 & 32 \\
\hline Total & 68 & 68 \\
\hline
\end{tabular}


Table 4 shows that the frequency distribution of respondents based on medication is the most consuming drugs, namely 68 respondents $(68 \%)$ while respondents who do not take drugs are 32 respondents (32\%).
Table 5 Distribution of Respondents Frequency Based on Sports $(n=100)$

\begin{tabular}{ccc}
\hline Sport & Total & $\begin{array}{c}\text { Percent } \\
(\%)\end{array}$ \\
\hline Frequent & 44 & 44 \\
Non Frequent & 56 & 56 \\
\hline Total & 100 & 100 \\
\hline
\end{tabular}

Table 5 shows that the frequency distribution of respondents based on exercise is the most in the irregular category with 56 respondents while the irregular is 44 respondents.

\section{Bivariate Analysis Result}

\section{Table 6 The Relationship Between Age And Blood Pressure}

\begin{tabular}{|c|c|c|c|c|c|c|}
\hline \multirow{3}{*}{ Age } & \multicolumn{3}{|c|}{ Blood Pressure } & \multirow{2}{*}{\multicolumn{2}{|c|}{ Total }} & \multirow[b]{2}{*}{ p-value } \\
\hline & \multirow{2}{*}{$\begin{array}{c}\text { Normal } \\
\mathbf{F}\end{array}$} & \multirow{2}{*}{$\begin{array}{c}\begin{array}{c}\text { Pre } \\
\text { Hypertension }\end{array} \\
\text { F }\end{array}$} & \multirow{2}{*}{$\frac{\text { Hypertension }}{\mathbf{f}}$} & & & \\
\hline & & & & $\mathbf{F}$ & $\%$ & \multirow{4}{*}{0.032} \\
\hline $26-35$ years & 4 & 23 & 11 & 38 & 100 & \\
\hline $36-45$ years & 1 & 30 & 31 & 62 & 100 & \\
\hline Total & 5 & 53 & 42 & 100 & 100 & \\
\hline \multicolumn{3}{|c|}{$\begin{array}{l}\text { Based on the results of the analysis in } \\
\text { table } 6 \text {, it can be seen that from } 38 \\
\text { respondents aged } 26-35 \text { years, there } \\
\text { were } 4 \text { respondents with normal blood } \\
\text { pressure, } 23 \text { respondents with pre- } \\
\text { hypertension, and } 11 \text { respondents with } \\
\text { hypertension. From } 62 \text { respondents } \\
\text { aged } 36-45 \text { years, } 1 \text { respondent had } \\
\text { normal blood pressure, } 30 \text { respondents }\end{array}$} & \multicolumn{4}{|c|}{$\begin{array}{l}\text { had pre-hypertension, and } \\
\text { respondents had hypertension. Based } \\
\text { the Chi Square test, it was found tha } \\
\text { value }=0.032(<0.05) \text {, which mea } \\
\text { that there is a relationship between a } \\
\text { and blood pressure in patients in } \\
\text { Intensive Care Unit (ICU) Bhayangka } \\
\text { Hospital Tk.I R. Said Sukanto. }\end{array}$} \\
\hline \multicolumn{7}{|c|}{ Table 7 Sex Relationship With Blood Pressure } \\
\hline \multirow{3}{*}{ Sex } & \multicolumn{3}{|c|}{ Blood Pressure } & \multirow{2}{*}{\multicolumn{2}{|c|}{ Total }} & \multirow[b]{2}{*}{ p-value } \\
\hline & Normal & $\begin{array}{c}\text { Pre } \\
\text { Hypertension }\end{array}$ & Hypertension & & & \\
\hline & $\mathbf{F}$ & $\mathbf{F}$ & f & $\mathbf{F}$ & $\%$ & \multirow{4}{*}{0.016} \\
\hline Male & 5 & 21 & 14 & 40 & 100 & \\
\hline Female & 0 & 32 & 28 & 60 & 100 & \\
\hline Total & 5 & 53 & 42 & 100 & 100 & \\
\hline
\end{tabular}


Based on the results of the analysis in table 7 , it can be seen that from 40 respondents with male sex there were 5 respondents normal blood pressure, 21 respondents with pre-hypertension, and 14 respondents with hypertension. Of the 60 respondents with female sex, 0 respondents had normal blood pressure,
32 respondents had pre-hypertension, and 28 respondents had hypertension. Based on the Chi Square test, -value = $0.016(<0.05)$ which means that there is a relationship between gender and blood pressure in patients in the Intensive Care Unit (ICU) Bhayangkara Hospital Tk.I R. Said Sukanto

Table 8 Race Relationship With Blood Pressure

\begin{tabular}{|c|c|c|c|c|c|c|}
\hline \multirow{3}{*}{ Race } & \multicolumn{3}{|c|}{ Blood Pressure } & & & \multirow[b]{2}{*}{ p-value } \\
\hline & Normal & $\begin{array}{c}\text { Pre } \\
\text { Hypertension }\end{array}$ & Hypertension & \multicolumn{2}{|c|}{ Total } & \\
\hline & $\mathbf{f}$ & $\mathbf{F}$ & f & $\mathbf{F}$ & $\%$ & \multirow{7}{*}{0.052} \\
\hline Java & 2 & 18 & 14 & 34 & 100 & \\
\hline Sunda & 0 & 19 & 7 & 26 & 100 & \\
\hline Betawi & 1 & 12 & 12 & 25 & 100 & \\
\hline Batak & 2 & 3 & 4 & 9 & 100 & \\
\hline Minang & 0 & 1 & 5 & 6 & 100 & \\
\hline Total & 5 & 53 & 42 & 100 & 100 & \\
\hline
\end{tabular}

Based on the results of the analysis in table 8 , it can be seen that from 34 respondents with Javanese race there were 2 respondents normal blood pressure, 18 respondents with prehypertension, and 14 respondents with hypertension. From 26 respondents with Sundanese race, 0 respondents had normal blood pressure, 19 respondents had pre-hypertension, and 7 respondents had hypertension. Of the 25 respondents with Betawi race, 1 respondent had normal blood pressure, 12 respondents had pre-hypertension, and 12 respondents had hypertension. Of the 9 respondents with Batak race, 2 respondents had normal blood pressure, 3 respondents had pre-hypertension, and 4 respondents had hypertension. Of the 6 respondents with Minang race, 0 respondents had normal blood pressure, 1 respondent pre-hypertension, and 5 respondents had hypertension. Based on the Chi Square test, it was found that value $=0.052(>0.05)$, which means that there is no relationship between race and blood pressure in patients in the Intensive Care Unit (ICU) Bhayangkara Hospital Tk.I R. Said Sukanto.

Table 9 Medication Relationship With Blood Pressure

\begin{tabular}{cccccccc}
\hline & \multicolumn{4}{c}{ Blood Pressure } & \multirow{2}{*}{ Total } & \multirow{2}{*}{ p-value } \\
\cline { 2 - 5 } Medication & Normal & $\begin{array}{c}\text { Pre } \\
\text { Hypertension }\end{array}$ & Hipertension & & & \\
\cline { 2 - 6 } & $\mathbf{f}$ & $\mathbf{f}$ & $\mathbf{f}$ & $\mathbf{f}$ & $\mathbf{\%}$ & \\
Non Drug Consumer & 4 & 20 & 8 & 32 & 100 & \multirow{2}{*}{0.009} \\
Drug Consumer & 1 & 33 & 34 & 68 & 100 & \\
\hline Total & 5 & 53 & 42 & 100 & 100 & \\
\hline
\end{tabular}

Based on the results of the analysis in table 9 , it can be seen that of the 32 respondents who did not take antihypertensive drugs, there were 4 respondents normal blood pressure, 20 respondents with pre-hypertension, and 
8 respondents with hypertension. Of the 68 respondents who took antihypertensive drugs, 1 respondent had normal blood pressure, 33 respondents had pre-hypertension, and 34 respondents had hypertension. Based

\section{Table 10 Sport Relationship With} Blood Pressure

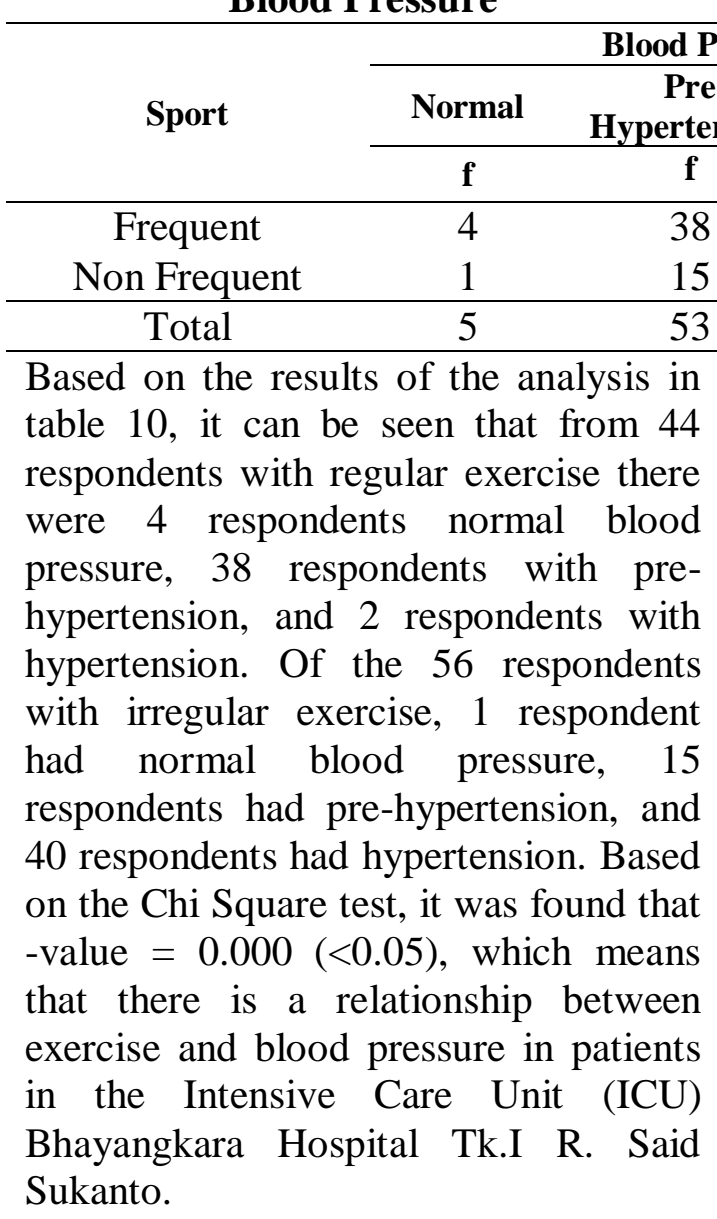

\section{DISCUSSION}

\section{Univariate Analysis}

Frequency Distribution of Respondents by Age

The proportion of respondents based on age, that is, most of the respondents are 36-45 years old or in the late adult category as much as $63 \%$.

The results of this study are in line with research conducted by Aris Sugiharto (2007) which examined the Risk Factors of Grade II Hypertension in the on the Chi Square test, the -value = $0.009(<0.05)$ which means that there is a relationship between medication and blood pressure in patients in the Intensive Care Unit (ICU) Bhayangkara R. Said Sukanto Hospital.

Community (Case Study in Karanganyar Regency) where for those aged 56-65 years had a 4.76 times d Pressuregreater risk of developing hypertension. tension hopertension than Tetie age oflu $e^{5-35}$ years. This if in accorflance with the theory which $^{2}$ states that ${ }^{4}$ hypettension. found th people 56 ged 3509 ears or older. With 42increasing 00 age 100 the risk of hypertension increases. Hypertension can occur at any age, but is most common at the age of 35 years or older. This is caused by natural changes in the heart, blood vessels and hormones. If these changes are accompanied by other factors, it can trigger hypertension (Bustam, 2007).

The results of research conducted by researchers are in line with research that proves that the late elderly have a risk of hypertension due to the aging process where the elasticity of blood vessels will decrease, thus allowing the occurrence of hypertension. Age is a risk factor that cannot be changed so it is recommended for patients to maintain a healthy lifestyle by reducing salt consumption, getting enough rest, avoiding stress and others to control blood pressure.

Frequency Distribution of Respondents by Gender

The proportion of respondents who are mostly female is $59 \%$, while the proportion of respondents is male is $41 \%$.

The results of this study are in accordance with the data from the Ministry of Health (2013), that the prevalence of cases of hypertension in Indonesia is more in women than men 
with a prevalence of $22.8 \%$ of cases in men and $28.8 \%$ of cases in women from the total number of patients. Hypertension. The results of this study are in line with research conducted by Sugiri (2012) in Central Java which states that the prevalence of hypertension in women is higher than men where the prevalence rate is $6 \%$ in men and $11 \%$ in women.

The results of this study are also supported by the theory according to Kowalski (2010) that more women experience hypertension because the nature of women who always put the interests of others, their family and friends above their own interests prevents them from getting medical care when the initial symptoms of cardiovascular disease appear. . Morbidity and death rates due to heart attack, stroke, angioplasty, bypass surgery in women are higher than men. The reason is that the development of the disease in women is much faster than in men. Women have a higher risk of developing hypertension after middle adulthood. This is because women have hormones that cause menstruation so that the risk of hypertension in women can be suppressed and only appears 710 years after menopause. During this menopause, estrogen levels decrease drastically (Sherwood, 2001). This results in a decrease in HDL (High Density Lipoprotein), an increase in LDL (Low Density Lipoprotein) which affects the elasticity of blood vessels (Price \& Wilson, 2005).

The results of research conducted by researchers are in line with research that proves that women have a risk of developing hypertension because in women the hormone estrogen is less, causing high LDL hormones. This LDL hormone can cause constriction of blood vessels and increase the risk of hypertension. Gender is a risk factor that cannot be changed so it is recommended for patients to maintain a healthy lifestyle by reducing salt consumption, getting enough rest, avoiding stress and others to control blood pressure.

Frequency Distribution of Respondents Based on Race

The proportion of respondents mostly came from the Javanese race with a total of 34 respondents or $34 \%$, the second largest Sundanese race respondents were 26 respondents or $26 \%$, Betawi was in third place with a total of 25 respondents or $25 \%$, while Minang and Batak each amounted to 9 and 6 respondents.

This is in line with the theory stated by Smeltzer and Bare (2002) that ethnicity or culture is one of the risk factors for hypertension.

According to the researcher's analysis, the balanced proportion of family cultural background factors shows that the family has not been able to modify the culture that has been passed down from generation to generation where the culture is related to maintaining family health, especially primary prevention of hypertension. According to the researcher's analysis, this is because the respondent's family mostly has Sundanese characteristics that have a culture or habit of consuming foods such as salted fish or fried foods.

The distribution of the frequency of respondents based on medication mostly consumed drugs, namely 68 respondents or $68 \%$, while respondents who consumed drugs were 32 respondents or $32 \%$.

The results of this study are in accordance with previous research by $\mathrm{E}$ Degli et al (2003) which stated that there was a relationship between the consumption of antihypertensive drugs and the incidence of uncontrolled hypertension $(\mathrm{p}=0.001, \mathrm{OR}=1.27)$. Non- 
adherence to taking antihypertensive drugs increased the risk of 1.27 times higher for uncontrolled hypertension than those who adhered to taking antihypertensive drugs.

The standard pharmacological treatment of hypertension recommended by the Committee of Hypertension Experts is diuretic drugs, beta blockers, calcium antagonists, and ACE inhibitors (Angiotensin Converting Enzyme) (Gunawan, 2007).

The results of research conducted by researchers are in line with research that proves that non-adherence to taking anti-hypertensive drugs can increase the risk of hypertension. Hypertension can be controlled if the management is done properly and correctly. One of the management of hypertension can be done with pharmacological techniques, namely by taking antihypertensive drugs.

The frequency distribution of respondents based on exercise is the most in the irregular category with 56 respondents while the irregular is 44 respondents.

The results of this study are in line with research conducted by Angraini (2014), which states that there is a significant relationship between physical activity or exercise with the incidence of hypertension, because the significance value (p) is 0.000 . The $p$ value is smaller than $=0.05$.

The results of this study are in accordance with the theory that lack of exercise will increase the likelihood of obesity and will facilitate the onset of hypertension (Suyono, 2011). Inactive people also tend to have a higher heart rate, so the heart muscle has to work harder with each contraction. The harder and often the heart muscle has to pump, the greater the pressure placed on the arteries (Sheps, 2015, in Aris 2017). A good frequency of exercise is if a person does exercise within a week, it is done 3-5 times and is done regularly with moderate intensity can lower blood pressure (Divine, 2006). Physical activity can improve heart rate at rest, total cholesterol levels, LDL levels and systolic and diastolic pressures for 6 weeks (Nurrahmani, 2012).

The results of research conducted by researchers are in line with research that proves that lack of exercise can increase the risk of hypertension. Lack of physical activity increases the risk of suffering from hypertension because it increases the risk of being overweight so it is recommended for patients to maintain a healthy lifestyle by means of regular exercise to control blood pressure.

\section{Bivariate Analysis Results}

The results showed that from 38 respondents aged 25-35 years, there were 4 respondents with normal blood pressure, 23 respondents with prehypertension, and 11 respondents with hypertension. Of the 62 respondents aged 36-45 years, 1 respondent had normal blood pressure, 30 respondents had pre-hypertension, and 31 respondents had hypertension. Based on the Chi Square test, it was found that value $=0.032(<0.05)$, which means that there is a relationship between age and blood pressure in patients in the Intensive Care Unit (ICU) Bhayangkara Hospital Tk.I R. Said Sukanto.

The results of this study are in line with research conducted by Budi et al (2011) that there is a significant relationship between the age of the elderly (60-90 years) with blood pressure. High hypertension is in line with increasing age caused by structural changes in large blood vessels, so that blood vessels become narrower and blood 
vessel walls become stiff, as a result of which systolic blood pressure increases (Rahajeng and Tuminah, 2009).

High hypertension is in line with increasing age caused by structural changes in large blood vessels, so that blood vessels become narrower and blood vessel walls become stiff, as a result of which systolic blood pressure increases (Rahajeng and Tuminah, 2009). Blood pressure will naturally increase as a person ages. One of the risk factors that cannot be modified for the incidence of hypertension is increasing age, so that the elderly with hypertension have a higher risk for the incidence of heart disease, stroke, and kidney failure (Rahajeng and Tuminah, 2009).

Based on the results of this study indicate that there is a relationship between age and blood pressure. With increasing age, the hemodynamic system of the body will also decrease so that it will be susceptible to various types of diseases including hypertension.

The results showed that from 40 male respondents, there were 5 respondents with normal blood pressure, 21 respondents with pre-hypertension, and 14 respondents with hypertension. Of the 60 respondents with female sex, 0 respondents had normal blood pressure, 32 respondents had pre-hypertension, and 28 respondents had hypertension. Based on the Chi Square test, it was found that -value $=0.016(<0.05)$, which means that there is a relationship between gender and blood pressure in patients in the Intensive Care Unit (ICU) Bhayangkara Tk.I R. Said Sukanto Hospital.

The results of this study are in line with research conducted by Sarasaty (2011) which proves that there is no relationship between gender and hypertension in the elderly. In this study, the results of univariate analysis showed that the proportion of female elderly was higher than male elderly, namely 46 women and 23 men who had hypertension. In addition, it is also known that the elderly who are female are more likely to suffer from hypertension.

Gender is very closely related to the occurrence of hypertension where in women it is higher when a woman experiences menopause, this is also supported by the opinion (Cortas 2008), in Anggraini (2011), said that women who have not experienced menopause are protected by the hormone estrogen which plays a role in increase levels of High Density Lipoprotein (HDL). High levels of HDL cholesterol is a protective factor in preventing the process of atherosclerosis. The protective effect of estrogen is thought to explain the presence of premenopausal female immunity. This is in accordance with the opinion (Yuliarti 2007), which states that there is a significant relationship between gender and the incidence of hypertension. This shows that the incidence of hypertension in women is influenced by levels of the hormone estrogen. The estrogen hormone will decrease in levels when women enter old age (menopause) so that women become more susceptible to hypertension. Research conducted (Rayhani 2013), regarding the relationship between gender and the incidence of hypertension in patients seeking treatment at the Adult Polyclinic of Bangkinang Health Center, it was found that women suffer from hypertension more than men, namely $51 \%$ vs. $49 \%$ and the results of the study (Oktora 2007), also It was found that women suffer from hypertension more than men, namely $58 \%$ vs $42 \%$. 
Based on the results of this study indicate that there is a relationship between gender and blood pressure. Women are at greater risk of blood pressure than men, because women have high levels of the hormone estrogen which can increase cholesterol levels which can inhibit the process of blood flow in the body so that it can cause high blood pressure.

The results showed that from 34 respondents with Javanese race, 2 respondents had normal blood pressure, 18 respondents had pre-hypertension, and 14 respondents had hypertension. From 26 respondents with Sundanese race, 0 respondents had normal blood pressure, 19 respondents had prehypertension, and 7 respondents had hypertension. Of the 25 respondents with Betawi race, 1 respondent had normal blood pressure, 12 respondents had pre-hypertension, and 12 respondents had hypertension. Of the 9 respondents with Batak race, 2 respondents had normal blood pressure, 3 respondents had pre-hypertension, and 4 respondents had hypertension. Of the 6 respondents with Minang race, 0 respondents had normal blood pressure, 1 respondent pre-hypertension, and 5 respondents had hypertension. Based on the Chi Square test, it was found that value $=0.052(>0.05)$, which means that there is no relationship between race and blood pressure in patients in the Intensive Care Unit (ICU) Bhayangkara Hospital Tk.I R. Said Sukanto.

Race or ethnicity is closely related to their culture or culture. The Alas people prefer river meat and fish such as mujair, goldfish, catfish compared to sea fish such as tuna, dencis, shrimp and others because sea fish contains preservatives and, with a culture like this it can be seen that the risk factor for hypertension is greater in people who live in coastal areas or who are accustomed to eating salty food (Indrawati, 2009).

Community culture has the power to influence the selection of food ingredients used for consumption. The socio-cultural aspect of food is the function of food in a community that develops in accordance with environmental conditions, religion, customs, habits, and education of the community (Suhardjo, 2009).

Based on the results of this study indicate that there is no relationship between race and blood pressure. This is because the National Police Hospital is a Referral Center Hospital that stands in Jakarta, whose patients reside in Jakarta and its surroundings. People who live in the Jakarta area are people who come from various regions. The culture they bring to the Jakarta area will also change with the culture in Jakarta.

The results showed that from 32 respondents taking antihypertensive drugs there were 4 respondents normal blood pressure, 20 respondents with pre-hypertension, and 8 respondents with hypertension. Of the 68 respondents who did not take antihypertensive drugs, 1 respondent had normal blood pressure, 33 respondents had pre-hypertension, and 34 respondents had hypertension.

Based on the Chi Square test, the -value $=0.009(<0.05)$ which means that there is a relationship between medication and blood pressure in patients in the Intensive Care Unit (ICU) Bhayangkara Tk.I R. Said Sukanto Hospital.

This study is in line with research conducted by Mursiany, Ermawati, and Oktaviani (2013) which explains that the use of antihypertensive drugs can lower blood pressure.

Captopril is widely given in all types of hypertension. This is in accordance 
with the statement of Nafrialdy (2008) that Captopril is effective for mild, moderate, and severe hypertension. Captopril belongs to the class of drugs. ACE-Inhibitors, with the mechanism of action of this group, namely as an angiotensin II inhibitor which causes constriction of blood vessels and results in increased blood pressure. The formation of angiotensin II requires an enzyme called angiotensin converting enzyme, which converts angiotensin I to angiotensin II. So by inhibiting the production of angiotensin II, the walls of blood vessels will widen, resulting in a decrease in blood pressure (Tjay and Rahardja, 2014). There are also drugs that are given from the class of calcium antagonists for all types of hypertension, namely Nifedipine and Amlodipine. This drug is very useful in dealing with emergency hypertension because the initial dose of $10 \mathrm{mg}$ can lower blood pressure within 10 minutes (Nafrialdi, 2008). From the data above, it can be seen that, there were 6 times the administration of drugs from this group in the type of severe to very severe hypertension. According to Tjay and Rahardja (2014) this drug is used in mild to moderate hypertension. So the administration of drugs in patients with western hypertension to severe is not very effective. The mechanism of action of this class of drugs is to block calcium ions that cause blood pressure. This calcium ion is very important for the formation of bones and cardiac smooth muscle, due to stimulation, calcium ions outside the cell will enter the cell, so that there will be more calcium ions in the cell, and contraction of the heart muscle and arteries will shrink and result in blood pressure. increased (Tjay and Rahardja, 2014). Based on the results of this study indicate that there is a relationship between medication and blood pressure.
Patients with hypertension will generally receive antihypertensive drugs. The mechanism of the drug in reducing hypertension is by inhibiting calcium ions that cause blood pressure.

The results showed that from 44 respondents with regular exercise there were 4 respondents normal blood pressure, 38 respondents with prehypertension, and 2 respondents with hypertension. Of the 56 respondents with irregular exercise, 1 respondent had normal blood pressure, 15 respondents had pre-hypertension, and 40 respondents had hypertension. Based on the Chi Square test, it was found that -value $=0.000(<0.05)$, which means that there is a relationship between exercise and blood pressure in patients in the Intensive Care Unit (ICU) Bhayangkara Hospital Tk.I R. Said Sukanto.

The results of this study are in line with research conducted by Ilkafah (2004), which states that physical exercise or exercise has an effect on reducing blood pressure in the elderly with mild to moderate hypertension. From 15 samples of elderly women who regularly exercise, 11 elderly experienced a decrease in blood pressure of about $6 \mathrm{mmHg}$ for systolic and $3 \mathrm{mmHg}$ for diastolic, three elderly experienced a decrease in blood pressure of only about $1.5 \mathrm{mmHg}$ in systolic and diastolic. This can happen because the three elderly suffer from Diabetes Mellitus. Then one elderly did not experience a decrease in blood pressure or remained because the elderly had high cholesterol and often took over-the-counter medicines, such as headache drugs containing caffeine which can increase blood pressure so that the effects of exercise have not been seen within two months.

Research conducted by Rahajeng and Tuminah (2009) stated that based on 
physical activity or exercise, the proportion of respondents who lacked physical activity in the hypertension group was found to be higher (42.9\%) than the non-hypertensive group $(41.4 \%)$. The risk of this physical activity was found to be significantly 1.02 times compared to sufficient physical activity. The tendency to develop hypertension in someone who lacks physical activity is $30-50 \%$ (Forester and Siagian, 2004). Busyness in a fast-paced and machine-paced world causes people to become sedentary and is followed by stress which can invite various cardiovascular diseases such as heart disease, high blood pressure and stroke. This is often found in the middle, old and elderly age groups, especially in someone who does not do sports (Giriwoyo and Sidik, 2012).

Physical exercise is one of the efforts in the management of hypertension with a non-pharmacological approach in addition to diet regulation, smoking cessation and alcohol consumption. In the management of hypertension with a pharmacological approach, drugs are used. However, exercise is not recommended for hypertensive patients who have a systolic blood pressure of more than $170 \mathrm{mmHg}$ and or a diastolic blood pressure of more than $110 \mathrm{mmHg}$ (Afriwardi, 2009).

Based on the results of this study indicate that there is a relationship between exercise and blood pressure. Exercise or physical activity can dilate blood vessels and relax the heart muscle so that blood flow throughout the body will be more normal and affect blood pressure

\section{CONCLUSION}

The results showed that there was a close relationship between age, gender, medication and exercise with blood pressure. Blood pressure is very important to see someone has a problem or not with his health, therefore these blood pressure factors can be seen as modifiable or non-modifiable risks to control blood pressure. Controlling blood pressure can prevent noncommunicable diseases caused by high blood pressure such as heart disease, stroke, kidney function failure and others.

\section{Bibliography}

Ainnur Rahmanti, Dyah Kartika Putri. 2016. Mobilisasi Progresif Terhadap Perubahan Tekanan Darah Pasien Di Intensive Care Unit (Icu).Akper Kesdam IV/ Diponegoro Semarang

Anggraini, dkk. 2009. Faktor- Faktor yang Berhubungan dengan Kejadian Hipertensi Pada Pasien yang berobat di Poliklinik Dewasa Puskesmas Bangkinang Periode Januari 2009

Aru W, Sudoyo. 2009. Buku Ajar Ilmu Penyakit Dalam, jilid II, edisi V. Jakarta: Interna Publishing

BALITBANGKES. 2013. Riset Kesehatan Dasar. Jakarta : Kementrian Kesehatan.

Bickley L.S. dan Szilagyi P.G. Chapter 7, The Thorax and Lungs. In : Bickley L.S. dan Szilagyi P.G. Bates'. 2007. Guide to Physical Examination and History Taking.9th edition.Lippincott Williams \& Wilkins.

Bustan, 2015. Manajemen Pengendalian Penyakit Tidak Menular. Jakarta : Rineka Cipta.

Casey, Aggie., Benson, Herbert. 2012. Menurunkan Tekanan Darah. Jakarta: Kelompok Gramedia

Hanafie A. 2010. Peranan Ruangan Perawatan Intensif ( ICU ) Dalam 
Memberikan Pelayanan Di Rumah Sakit.

LeMone, P, \& Burke. 2009. Medical surgical nursing : Critical thinking in client care. (4th ed). Pearson Prentice Hall : New Jersey

Lewis. 2007. Medical Surgical Nursing, Assesment and Management of Clinical Problem. Seventh Edition. Volume 2. St. Louis. Missouri. Mosby.Elsevier INC

Nolan, Mary. 2010. Kehamilan \& Melahirkan. Jakarta: Arcan.

Notoatmodjo S. 2010. Promosi Kesehatan Teori dan Aplikasi. Jakarta: PT Rineka Cipta

Notoatmodjo S. 2012. Promosi Kesehatan dan Perilaku Kesehatan. Jakarta: PT Rineka Cipta.

Nursalam. 2014. Manajemen Keperawatan: Aplikasi Dalam Praktik Keperawatan Profesional. Jakarta: Salemba Medika.

Nursalam. 2008. Konsep dan Penerapan Metodologi Penelitian Ilmu Keperawatan. Jakarta: Salemba Medika.

Rab, H.T., 2010. Ilmu Penyakit Paru. Jakarta: Trans Info Media.

Rihiantoro, T., Nurachmah, E., \& Hariyati, R. T. S. 2013. Pengaruh Terapi Musik Terhadap status Hemodinamika pada pasien Koma di Ruag ICU Sebuah Rumah sakit di lampung. Jurnal keperawatan Indonesia.

Robinson, Joan. M dan Lyndon Saputra. 2014. Buku Ajar Visual Nursing
Jilid Satu. Tangerang Selatan: Binarupa Aksara Publisher

Rusdi \& Nurlaela I. 2009. Awas! Anda bisa mati cepat akibat hipertensi \& diabetes. Yogyakarta : Power Books (IHDINA).

Sugiyono. 2013. Metode Penelitian Pendidikan Pendekatan Kuantitatif, Kualitatif, dan $R \& D$. Bandung: Alfabeta.

Sutanto. 2010. Cekal (Cegah dan Tangkal) Penyakit Modern Hipertensi, Stroke, Jantung, Kolestrol, dan Diabetes. Yogyakarta: C.V Andi Offset.

Townsend, M.C. 2010. Psychiatric Mental Perawatan Kesehatan: Konsep Perawatan di Bukti-Based Practice 6 Ed., FA Davis Perusahaan

WHO. 2014. The world health report: 2012 : mental health : new understanding, new hope. Retrieved from www.who.int/whr/2012/en/ 
Journal Of Ageing And Family (JOAF)

Edition 1, No 1, October 2021

Ixxxii

http://ejournal.urindo.ac.id/index.php/JournalOfAgeingAndFamily/index 